\title{
PENINGKATAN KEMAMPUAN BERPIKIR ALJABAR MELALUI PEMBELAJARAN SCHEMA-BASED INSTRUCTIONDENGAN STRATEGI FOPS
}

\author{
Gelar Dwirahayu ${ }^{1)^{*}}$, Mia Halpiani ${ }^{2)}$, Dedek Kustiawati ${ }^{3)}$ \\ ${ }^{1,2,3)}$ Pendidikan Matematika, Fakultas Ilmu Tarbiyah dan Keguruan \\ Universitas Islam Negeri Syarif Hidayatullah Jakarta \\ "gelar.dwirahayu@uinjkt.ac.id
}

\begin{abstract}
Abstrak
Mengajarkan matematika bukanlah hal yang mudah, perlu di rencanakan sebuah pembelajaran yang dapat membantu siswa memahami matematika dengan mudah.Dalam penelitian ini dikembangkan sebuah pembelajaran dengan menggunakan pendekatan Schema-Based Instruction (SBI) dengan strategi FOPS dalam meningkatkan kemampuan aljabar siswa.Metode yang digunakan adalah kuasi eksperimen dengan desain randomized control group posttest only, sampelnya adalah siswa SMP Negeri 12 Tangerang Selatan sebanyak 2 kelas, kelas pertama sebagai kelas eksperimen dan kelas kedua sebagai kelas kontrol. Instrumen yang digunakan yaitu Tes Kemampuan Berpikir Aljabar sebanyak 8 soal, yang diuji dengan menggunakan uji perbedaan dua rata-rata. Hasil Penelitian menunjukkan $\mathrm{t}_{\text {hitung }}=2,180$ dan $\mathrm{t}_{\text {tabel }}=1,99$, karena $\mathrm{t}_{\text {hitung }}>\mathrm{t}_{\text {tabel. }}$. Hasil penelitian menunjukkan bahwa kemampuan berpikir aljabar siswa yang diajarkan menggunakan pendekatan SBI dengan strategi FOPS lebih tinggi dibandingkan dengan kemampuan aljabar siswa yang diajarkan menggunakan pembelajaran konvensional.
\end{abstract}

Kata Kunci:pendekatan Schema-Based Instruction, FOPS, kemampuan berpikir aljabar

\section{PENDAHULUAN}

Matematika merupakan salah satu ilmu pengetahuan yang aplikasinya sangat dibutuhkan dan banyak diterapkan dalam kehidupan manusia, seperti sebagai dasar pengembangan teknologi atau disiplin ilmu lain serta memajukan daya pikir manusia. Salah satu cabang matematika yang harus dikuasai siswa dalam pembelajaran matematika adalah materi aljabar. Sebagaimana tertuang dalam
Permendikbud Nomer 68 tahun 2013 tentang kerangka dasar dan struktur kurikulum pembelajaran matematika, dan NCTM (2002) dinyatakan bahwa materi aljabar merupakan salah satu materi matematika yang harus dikuasai oleh siswa mulai dari tingkat TK sampai tingkat menengah bahkan sampai pendidikan di perguruan tinggi.

Berpikir aljabar merupakan dasar dari kemampuan berpikir matematika 
(Hayati, 2013), terutama kemampuan bernalar siswa, karena materi aljabarsebagai salah satu cabang matematika memiliki karakteristik khusus yaitu konsep yang berhubungan dengan kajian kuantitas, hubungan, dan struktur (Warsitasari, 2015) matematis. Aljabar tidak menggunakan angka/numeric akan tetapi mempelajari tentang perubahan kuantitas menjadi symbol, hubungan antar simbol dan manipulasi simbol-simbol. Untuk memudahkan belajar aljabar, siswa harus memiliki pemahaman konseptual tentang penggunaan simbol-simbol. Sebagai dasar dalam berpikir matematik, kemampuan aljabar diharapkan mampu melatihkemampuan berpikir tingkat tinggi siswa - berpikir kritis, kreatif, bernalar dan berpikir abstrak (Yunami, 2015).

$$
\text { Selanjutnya NCTM }
$$
menyatakan bahwa algebraic competence is important in adult life, both on job and as preparation for post secondary, kalimat tersebut menunjukkan bahwa manfaat dari aljabar tidak hanya dirasakan ketika sedang belajar, akan tetapi akan berguna di masa yang akan datang. Materi pelajaran matematika tingkat tinggi akan banyak menggunakan aljabar daripada numerik atau angka-angka dan hal ini diimplementasikan dalam kehidupan sehari-hari.

Namun berdasarkan data yang ada di lapangan memperlihatkan bahwa masih adanya beberapa kesulitan yang dihadapi siswa dalam kemampuan aljabar antara lain terjadi miskonsepsi pada penyelesaian operasi aljabar (Dwirahayu, 2018; Holmes, 2013), rendahnya kemampuan siswa dalam konsep aljabar dan keterampilan yang rendah dalam menyelesaikan operasi bentuk aljabar (Warsitasari 2015), rendahnya kemampuan siswa dalam

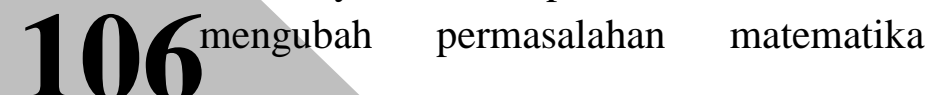

menjadi model matematika dalam bentuk tulisan atau simbol-simbol (Yunarni, 2015), dan kemungkinan terjadi kesulitan dalam penyesuaian cara berpikir siswa dari berpikir aritmatika (operasi hitung dengan angka) menuju berpikir aljabar (operasi dengan menggunakan variabel) (Kieran, 2004).

Akibatnya, siswa menyelesaikan soal-soal matematika dengan cara meniru atau mengikuti pola jawaban yang dicontohkan oleh guru. Upaya untuk mengatasi rendahnya kemampuan berpikir aljabar siswa dengan memilih pembelajaran yang dapat mengembangkan kemampuan berpikir aljabar. Salah satu alternatif pendekatan pembelajaran yang dapat digunakan meningkatkan kemampuan berpikir aljabar adalah pendekatan SBI dengan strategi FOPS.

Aljabar merupakan perkembangan dari aritmatika, jika aritmatika berkaitan dengan angka sedangkan aljabar melakukan perhitungan atau operasi matematis yang melibatkan angka sekaligus penggunaan simbol-simbol sebagai bahasa untuk mengungkapkan ideide matematika. Sebagaimana diungkapkan oleh Patton (2012) bahwa berpikir aljabar adalah kemampuan untuk mengoperasikan bilangan dilambangkan dengan variabel, dan kegiatan dalam berpikir aljabar adalah aktivitas yang menggabungkan proses matematika dengan salah satu ide besar aljabar, seperti memahami pola dan fungsi, mewakili situasi dengan simbol, penggunaan model matematika, dan menganalisis perubahan (Vennebush, 2005).

Salah satu hal mendasar dalam berpikir aljabar adalah pemahaman mengenai konsep kesetaraan atau ekivalensi, yang melibatkan penggunaan variabel. Variabel diartikan sebagai simbol 
yang digunakan untuk menunjukkan atau mewakili nilai/bilangan tertentu yang bervariasi (Knuth, 2011). Penggunaan variabel atau simbol dalam berpikir aljabar sangat penting untuk membuat generalisasi dan model matematika. Sedangkan maksud dari ekuivalensi atau kesamaan dalam berpikir aljabar adalah konsep kesetaraan simetris dan transitif, yang disebut kesamaan ekspresi dikiri dan kanan dari tanda sama dengan artinya nilai ekspresi dikiri dan kanan harus sama (Kieran, 2004). Dalam berpikir aljabar tanda sama dengan tidak lagi dipandang sebagai simbol hasil operasi seperti dalam berpikir aritmatika melainkan harus dipandang sebagai simbol ekuivalensi yaitu simbol yang menunjukkan hubungan antara dua kuantitas. Hal ini akan mempermudah siswa dalam melakukan generalisasi aau operasi variabel.

Ada tiga kondisi menurut Radford (2013) yang merupakan karakteristik berpikir aljabar yaitu:

1. Indeterminacy: artinya bahwa permasalahan yang dimunculkan melibatkan bilangan yang tidak diketahui atau biasa dikenal dengan variabel.

2. Denotation: artinya bahwa operasi dala, aljabar sama dengan operasi dalam aritmatika, namun pada konsep aljabar, bilangan dinyatakan dengan menggunakan symbol atau notasi, salah satunya menggunakan lambang alfanumerik atau alfhabet.

3. Analyticity: artinya bahwa aljabar dapat menunjukkan kuantitas yang tidak pasti (variable) dan diperlakukan seperti bilangan biasa. Namun dibutuhkan kemampuan untuk mampu menganalisis variable ketika dioperasikan seperti bilangan yang diketahui kuantitasnya (seperti dijumlahkan, dikurangi, dikalikan atau dibagi). Menebak angka tidak diperbolehkan dalam berpikir aljabar.

Selain tiga karakteristik dalam berpikir aljabar, kemampuan berpikir aljabar juga diartikan sebagai penggambaran aktifitas untuk menerapkan konsep aljabar yang meliputi aktivitas menggeneralisasi, aktivitas mentransformasi, dan aktivitas global meta-level (Kieran, 2004) sebagai formulasi ide matematika yang semula dinyatakan dalam bentuk aritmatika kemudian dinyatakan dalam bentuk simbol sebagai model. Aktivitas tersebut dijelaskan sebagai berikut:

1. Aktivitasmenggeneralisasi aljabar. Aktivitas ini merupakan kegiatan dalam menyatakan persamaan matematik dalam bentuk aljabar. Konsep aljabar tidak sama dengan konsep aritmatika, pada aritmatika siswa diminta untuk menemukan penyelesaian, sedangkan pada aljabar siswa dituntut untuk mampu membuat model matematika yang melibatkan penggunaan simbol atau notasi, sehingga siswa akan terbiasa melakukan operasi hitung pada aljabar dengan memperhatikan kesetaraan persamaan matematisnya.

2. Aktivitas mentransformasi. Dalam menyelesaikan persamaan aljabar, ada beberapa aktivitas yang dapat dilakukan antara lain: mengelompokkan variable yang sejenis, melakukan faktorisasi, melakukan asosiasi, substitusi, menjumlahkan atau mengalikan persamaan matematis dalam bentuk polynomial, menyelesaikan persamaan, menyederhanakan bentuk aljabar, bekerja dengan cara menyatakan ekivalensi model atau- 
persamaan matematid dan lain sebagainya.

3. Aktivitas global meta-level. Aktivitas ini merupakan tahapan yang lebih tinggi, karena aktivitas ini lebih ditekankan pada pemanfaatan aljabar daam menyelesaikan masalah matematika diluar konsep aljabar, misalnya pemodelan matematis pada konsep geometri, aljabar digunakana untuk pemecahan masalah sehari-hari, aljabar digunakan sebagai pemodelanmatematis dari permasalahan sehari-hari, menganalisis hubungan yang terjadi dari dua keadaaan atau dua kejadian, menganalisis perubahan yang terjadi prakiraan cuaca, nilai penguatan mata uang Rupiah terhadap Dolar Amerika, aljabar digunakan untuk menggeneralisasi,membuktikan dan memprediksi kejadian sehari-hari diluar konteks matematika.

Ditinjau dari kurikulum pendidikan di sekolah menengah, konsep aljabar menjadi salah satu materi yang harus diajarkan kepada siswa di tingkat sekolah menengah pertama dan sekolah menengah atas. Dengan memperhatikan karakteristik khusus konsep aljabar di sekolah, maka dalam penelitian ini, ada empat indikator (Kieran, 2004; NCTM, 2000) yang digunakan untuk mengukur kemampuan aljabar siswa pada tingkat sekolah menenga pertama, yaitu;

1. Membuat model matematika yang mengggunakan simbol untuk menyelesaikan masalah.

2. Membuat prediksi dari suatu permasalahan berdasarkan informasi dari soal cerita.

3. Mengeneralisasi pola aritmatika yang melibatkan variabel dari suatu masalah.
4. Melakukan pembuktian dari suatu permasalahan yang melibatkan persamaan aljabar

Pembelajaran yang dikembangkan dalam penelitian ini adalah Pendekatan Schema-Based Instruction (SBI) dengan menggunakan strategi FOPS. SchemaBased Instructionadalah pendekatan pembelajaran yang menggunakan skema sebagai sutau sarana bagi siswa untuk melakukan analisis struktur masalah. Skema merupakan gambaran informasi penting atau ide-ide matematis yang diberikan dalam suatu permasalahan, dan melalui skema tersebut siswa mempu menghubungkan bagaimana keterkaitan pada masing-masing unsur tersebut, sehingga dari skema yang dibuat akan memudahkan siswa menyelesaikan masalah. Pendekatan SBI terdiri dari dua tahap yaitu, pembelajaran skema dan pembelajaran solusi. Pembelajaran skema masalah (siswa mengidentifikasi struktur masalah dan merepresentasikannya dengan menggunakan skema) sedangkan pembelajaran solusi masalah (siswa memecahkan informasi yang tidak diketahui dalam soal menggunakan strategi pemecahan masalah heuristik) (Xin, Jitendra, Buchman, 2005)

Strategi FOPS merupakan tahapan pembelajaran yang mengadopsi pendekatan pemecahan masalah menurut Polya. Strategi pemecahan masalah FOPS terdiridari empattahappemecahan, yaitu: (F) find the problem type (menemukan tipemasalahnya), (O) organize the information in the problem using diagram (mengorganisasikan informasi masalah menggunakan diagram), $(\mathrm{P})$ plan to solve the problem (merencanakan pemecahan masalah), (S) solve the problem (terahir memecahkan masalahnya) (Jitendra, 2012). 
Desain pembelajaran matematika yang menggabungkan antara schema based instruction (SBI) dengan strategi FOPS (gambar 1) diharapkan siswa mampu menyelesaikan masalah yang berkaitan dengan konsep aljabar, sebagaimana yang dikemukakan oleh Polya tentang pemecahan masalah sebagai salah satu pendekatan yang dapat digunakan dalam pembelajaran matematika, dan juga siswa terlatih merepresentasi ide-ide matematis secara singkat dan jelas dengan menggunakan skema.

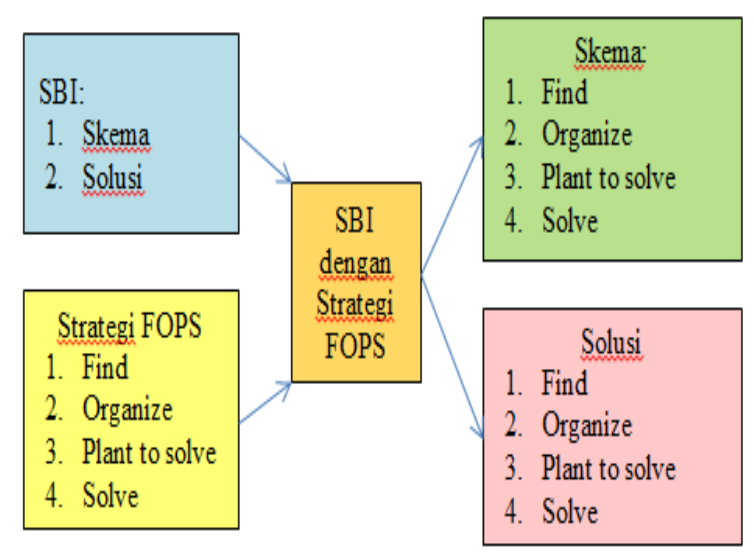

Gambar 1. Modifikasi SBI dan FOPS

Pada dasarnya bahwa pembelajaran yang digunakan adalah menggunakan pendekatan SBI yang terdiri dari dua tahap pembelajaran yaitu tahap skema dan tahap solusi. Namun setelah dimodifikasi, maka proses pembelajaran pada masing-masing tahap dibuat tahapan kembali secara sistematis yaitu menggunakan empat tahap pada strategi FOPS.

Pembelajaran pada tahap skema menekankan pada kemampuan siswa dalam mengidentifikasi dan pemetaan masalah yang disajikan dalam bentuk skema. Dari skema yang dibuat siswa akan tergambarkan sejauh mana siswa mampu memahami masalah yang disajikan. Dengan membuat skema menurut Xin
(2008) dapat membantu siswa memahami konsep dan membuat hubungan dan memilah informasi sehingga membantu dalam melakukan pembuktian maupun generalisasi. Sedangkan tahap solusi menekankan pada kemampuan siswa menggunakan empat langkah strategi FOPS yang digunakan sebagai bantuan acuan siswa dalam menyelesaikan masalah matematika sesuai (Griffin, 2009).

Tahapan pembelajaran pendekatan SBI dengan strategi FOPS terdiri dari 2 tahap yaitu pembelajaran skema masalah dan pembelajaran solusi masalah dengan masing-masing tahap menggunakan empat langkah-langkah strategi FOPS.Tahaptahap pembelajaran pendekatan SBI dengan strategi FOPS didalam kelas yaitu;

1. Pembelajaran skema masalah. Pada tahap ini siswa menerjemahkan dan mengelaborasi informasi dalam masalah dan memetakannya ke dalam diagram skema. Kegiatan siswa pada tahap ini mengikuti tahapan stategi FOPS, namun disingkat lagi menjadi dua tahap, yaitu:

a. Find the problem typedan Organize the information in the problem.

Pada tahap ini siswa diarahkan untuk membuat skema, melatih siswa untuk menggunakan berbagai notasi atau simbol matematika dalam mengkonstruksi pemodelan matematis sebelum menyelesaikan permasalahan

b. Plan to solve the problem dan Solve the problem.

Pada tahap ini siswa diarahkan untuk memahami konsep aljabar dengan tujuan menggeneralisasi pola aritmatika dalam bentuk persamaan aljabar dari suatu masalah 
2. Pembelajaran solusi masalah. Selama tahap ini siswa memecahkan masalah yang diberikan oleh guru, pada tahap ini siswa menerapkan konsep yang telah dipelajari untuk memecahkan masalah yang lebih kompleks. Kegitan siswa pada tahap ini mengikuti tahapan FOPS:

a. Find the problem type.

Diberikan masalah sebagai berikut:

Di sebuah kota akan dibangun tempat perkemahan baru yang berbentuk trapesium sama kaki. Perkemahan tersebut akan dibagi menjadi tiga area yaitu area pertama untuk membangun tempat parkir, area kedua untuk tempat berkemah dan area ketiga mushola.

Ukuran dari ketiga area perkemahan tersebut seperti pada denah di bawah.

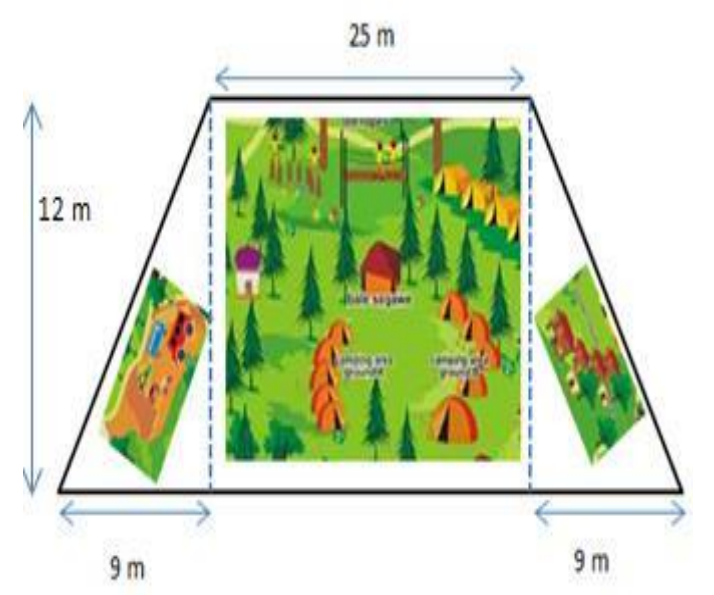

Hitunglah berapa luas tanah yang diperlukan untuk membangun tempat perkemahan tersebut? Jika sekeliling tempat perkemahan tersebut akann dipagar, maka berapakah panjang pagar yang harus disiapkan?

b. Organize the information in the problem.
Dari permasalahan yang disajikan, siswa diminta untuk mengidentifikasi permasalahan, menyebutkan perihal apa saja yang telah diketahui dalam soal dan apa yang ditanyakan dalam soal.

c. Plan to solve the problem.

Setelah siswa memahami permasalahan, selanjutnya siswa membuat skema sebagai salah satu cara untuk memudahkan penyelesaian permasalahan. Siswa dibantu LKS untuk membuat skema, tujuannya agar pola berpikir siswa terarah.

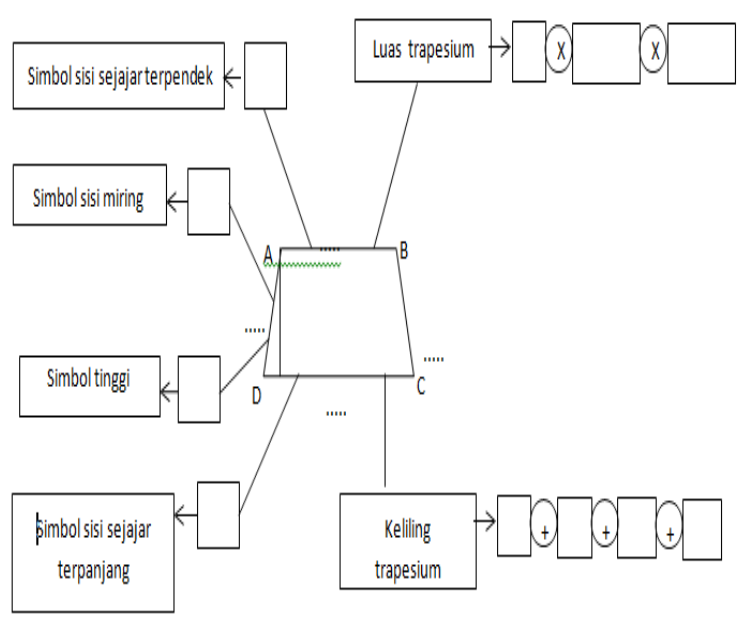

Pada skema di atas, nampak kotakkotak isian yang harus diisi oleh siswa sesuai dengan permasalahan yang diberikan di awal.

d. Solve the problem.

Setelah siswa mengisi skema, selanjutnya siswa diminta untuk menyelesaikan permasalahan

\section{METODE PENELITIAN}

Metode penelitian yang digunakan adalah Quasi Eksperimen dengan Desain penelitian Randomized Posttest Only Control Group Design.Penelitian dilaksanakan pada tahun ajaran 2016/2017 
semester genap. Sampel yang digunakan adalah siswa SMP Negeri 12 Kota Tangerang Selatan sebanyak dua kelas yaitu kelas VII 6 sebagai kelas eksperimen sebanyak 37 siswa dan kelas VII 8 sebagai kelas kontrol sebanyak 37 siswa juga.

Siswa di kelas eksperimen proses pembelajarannya menggunakan Schema Based Learning dengan srategi FOPS, sedangkan siswa di kelas kontrol, proses pembelajaran menggunakan strategi pembelajaran ekspositori. Ekspositori menekankan kepada proses penyampaian materi secara verbal dari guru. Hal ini sesuai dengan pendapat Sanjaya (2013) dan Ruseffendi (2006) bahwa metode ekspositori dianggap sebagai cara mengajarkan konsep matematika yang paling efektif dan efisien.Guru lebih berperan aktif dalam penyampaian informasi atau materi, siswa mendengarkan, mencatat selanjutnya dilakukan diskusi jika masih ada siswa yang belum memahami materi maupun kesulitan dalam menyelesaikan soal-soal latihan. Proses pembelajaran diakhiri dengan pemberian latihan soal.

Instrumen yang digunakan dalam penelitian ini berupa soal aljabar berbentuk uraian sebanyak 8 soal pada pokok bahasan bangun datar, soal yang digunakan merupakan soal implementasi atau generalisasi dari konsep aljabar.

Data kemampuan aljabar siswa selanjutnya dianalisis dengan menggunakan uji t pada $\alpha=5 \%$ untuk mengetahui apakah terdapat perbedaan yang signifikan antara kemampuan berpikir aljabar siswa di kelas eksperimen dan siswa di kelas kontrol.

\section{HASIL DAN PEMBAHASAN}

Data kemampuan berpikir aljabar siswa pada kelas eksperimen dan kelas kontrol disajikan pada table 1 .

Tabel 1. Data Kemampuan Berpikir Aljabar

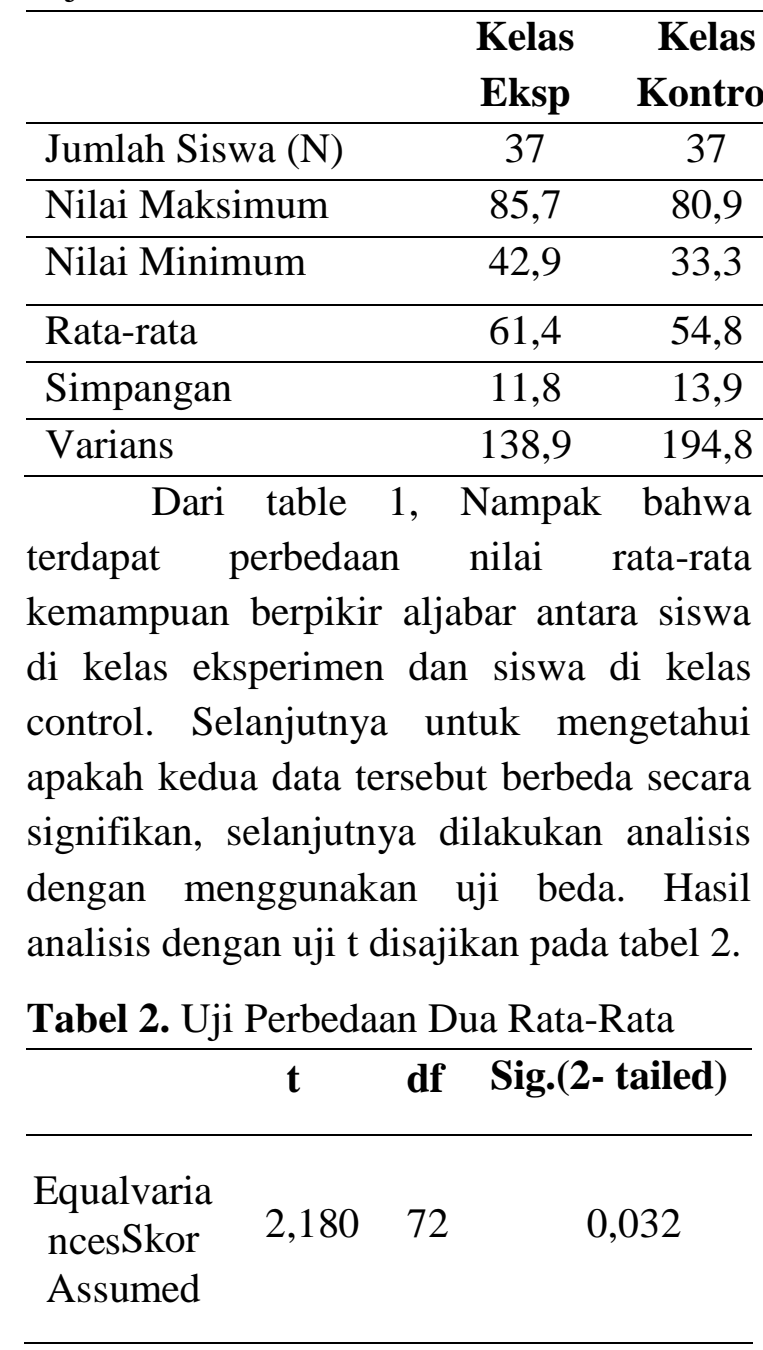

Dengan mengambil taraf signifikansi $\alpha=0.05$ diperoleh hasil pengujian dua ratarata $t_{\text {hitung }}=2,180$ dan $t_{\text {tabel }}=1,99$. Maka $t_{\text {hitung }}>t_{\text {tabel }}$ hal ini berarti bahwa tolak $\mathrm{H}_{0}$, dengan kata lain bahwa kemampuan aljabar siswa yang belajar menggunakan SBI dengan strategi FOPS lebih tinggi dibandingkan siswa yang diajarkan dengan pembelajaran konvensional.

Ditinjau dari indikator berpikir aljabar terlihat bahwa tidak semua indikator kemampuan berpikir aljabar 
siswa yang diajarkan menggunakan pendekatan SBI dengan strategi FOPS lebih tinggi dibandingkan siswa yang diajarkan dengan pembelajaran konvensional. Berikut adalah kemampuan berpikir aljabar siswa pada kelas ekperimen dan kelas kontrol berdasarkan indikator kemampuan berpikir aljabar, disajikan dalam bentuk grafik.

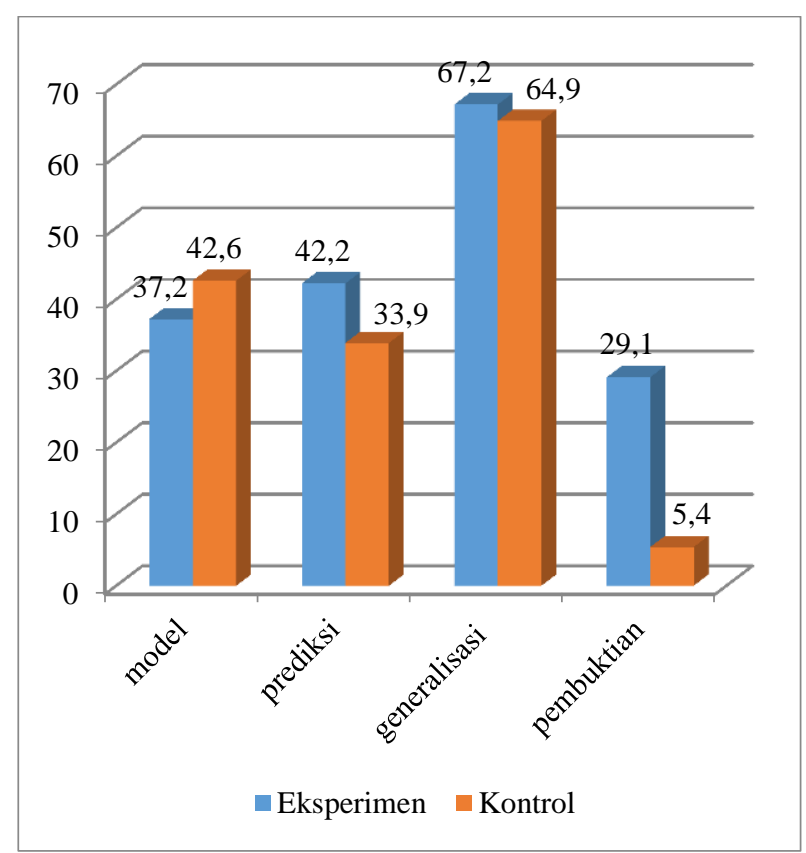

Gambar 2. Rata-rata Kemampuan Berpikir Aljabar Siswa Per Indikator

Dari gambar 2 terlihat bahwa kemampuan berpikir aljabar siswa di kelas eksperimen lebih tinggi daripada kemampuan berpikir aljabar siswa di kelas control pada setiap indikator. Hanya satu indikator yang capaiannya lebih rendah dibandingkan dengan kelas control yaitu indikator "Menggunakan simbol dalam pemodelanmatematis untuk menyelesaikan masalah" sedangkan indikator berpikir aljabar di kelas eksperimen yang paling tinggi adalah "Mengeneralisasi pola aritmatika dari suatu masalah". Selain itu indikator yang ke empat yaitu "Melakukan pembuktian dari suatu persamaan dalam aljabar" capaiannya paling rendah.

Rendahnya kemampuan siswa dalam melakukan pembuktian persamaan aljabar, dikarenakan siswa tidak terbiasa dengan soal-soal pembuktian. Siswa lebih menyukai menyelesaikan permasalahan atau soal-soal matematika dalam bentuk hitungan. Meskipun fungsi aljabar itu sendiri menjadi tools dalam menyelesaikan soal-soal matematika yang disajikan tidak pada aspek kuantitas akan tetapi penyelesaian kuantitas yang menggunakan notasi atau symbol-simbol (Patton, 2012). Kemampuan siswa dalam menganalisis kesamaan persamaan matematika yang melibatkan beberapa variable atau notasi masih rendah, sehingga perlu diberikan penjelasan yang lebih tentang sifat-sifat pada operasi aljabar.

Temuan menarik dalam penelitian ini adalah pada indikator menggunakan simbol dalam pemodelan matematis untuk menyelesaikan masalah, siswa yang belajar dengan pendekatan konvensional lebih tinggi daripada siswa yang belajar dengan SBI. Proses pembelajaran di kelas eksperimen dengan menggunakan SBI, siswa diberikan kebebasan untuk membuat skema dari permasalahan yang ada, kemudian siswa diminta untuk membuat model matematika berdasarkan skema yang telah dibuat, idealnya bahwa pembelajaran matematika dengan SBI akan melatih kemampuan siswa dalam membuat model matematika yang melibatkan variable atau symbol-simbol. Kebebasan inilah yang diduga oleh peneliti sebagai salah satu penyebab siswa kurang memahami konteks variable atau symbol sebagai pengganti kuantitas yang tidak tentu, sedangkan di kelas control, proses pembelajaran didominasi oleh penjelasan dari guru, dengan menggunakan 
pendekatan teacher center, guru menjelaskan secara detil berbagai jenis variable atau notasi yang dapat digunakan, bahkan siswa dibimbing untuk menemukan atau menggunakan symbol atau variable yang mudah diingat dan mewakili benda yang sedang dibicarakan.

Selain itu, skema yang digunakan dalam penelitian ini merupakan skema yang berbentuk isian, sehingga diharapkan siswa menjadi lebih fokus pada permasalahan yang disajikan kemudian mampu menyusun persamaan atau model matematika dengan baik, kenyataannya siswa menjadi kebingungan karena pada penggunaan LKS siswa mengisi variable dengan huruf-huruf atau notasi matematika tertentu.

Berikut adalah contoh soal pemodelan: "Sebuah papan tulis berbentuk persegi panjang memiliki panjang yang ukurannya adalah 3 kali lebarnya. Kemudian panjang papan tulis akan ditambah $10 \mathrm{~cm}$ dari ukuran semula dan lebarnya ditambah $22 \mathrm{~cm}$ dari ukuran semula, sehingga keliling papan tulis sekarang menjadi $432 \mathrm{~cm}$. Buatlah model matematikanya! Berapakah selisih luas papan tulis setelah diperbesar dengan papan tulis semula?

Untuk menjawab pertanyaan tersebut, pada mulanya siswa baik di kelas eksperimen maupun di kelas kontrol dapat memahami masalah dengan menunjukkan kondisi apa yang diketahui, yaitu dengan menuliskan: Diketahui panjang $=3 \times$ lebar. Jika panjangnya ditambah $10 \mathrm{~cm}$ dan lebarnya ditambah $22 \mathrm{~cm}$ maka kelilingnya menjadi $432 \mathrm{~cm}$.

Selanjutnya siswa di kelas eksperimen membuat persamaan matematis sebagai berikut

$k=2(p+l)=2(3 l+l)=2(4 l)$

$k=8 l$
$432=8 l$

$l=\frac{432}{8}=54$

jadi $l=32$

$p=3 l=96$

Jadi $p=86$

Sedangkan siswa di kelas control membuat model matematis sebagai berikut:

$k=2(p+l)$

$k=2(3 l+1)+(l+22)$

$k=6 l+20+2 l+44$

$k=8 l^{2}+64$

Nampak pada jawaban kedua siswa, siswa yang di kelas kontrol mengalami kesulitan dalam mengoperasikan bentuk aljabar $\left(6 l+2 l=8 l^{2}\right)$, sedangkan siswa di kelas eksperimen kesalahan memahami persoalan, yang seharusnya panjang dan lebar yang baru adalah penambahan dengan bilangan tertentu, sedangkan siswa malah mengurangi angkanya. Dengan demikian bisa disimpulkan bahwa siswa di kelas eksperimen belum mampu menggunakan skema dalam menyelesaikan masalah matematika.

Dari jawaban siswa di kelas eksperimen maupun kelas kontrol terlihat pada kedua siswa sudah mampu menggunakan simbol untuk mewakili suatu informasi pada permasalahan yang disajikan. Namun siswa belum dapat menerjemahkan atau menginterpretasi masalah matematika ke dalam persamaan ke dalam model matematika, dan ada juga siswa yang belum mampu melakukan penyelesaian operasi bentuk aljabar (operasi kuantitas yang melibatkan notasi atau symbol atau variable).

\section{SIMPULAN DAN SARAN}

1. Pembelajaran dengan menggunakan schema based instruction dengan 
strategi FOPS dapat meningkatkan kemampuan berpikir aljabar siswa pada

2. Kemampuan berpikir aljabarsiswa yangbelajar matematika menggunakan pendekatan Schema-Based Instruction (SBI) dengan strategi FOPS lebih tinggi dibandingkan dengan kemampuan berpikir aljabar siswa yang belajar matematika menggunakan pendekatan konvensional.

3. Pembelajaran dengan schema based instruction masih harus dikembangkan lagi khususnya pada tahap pembuatan skema, karena dengan skema diharapkan siswa akan lebih mudah dalam memahami permasalahan khususnya dalam pembuatan model atau persamaan matematis.

\section{UCAPAN TERIMA KASIH}

Peneliti mengucapkan terima kasih kepada Kepala Sekolah, Guru Matematika dan Siswa di SMP Negeri 12 Tangerang Selatan yang sangat kooperative dalam pelaksanaan penelitian ini, selain itu terima kasih juga disampaikan kepada pada Dosen di Jurusan Pendidikan Matematika UIN Syarif Hidayatullah Jakarta atas dukungannya kepada peneliti, sehingga penelitian ini dapat diselesaikan.

\section{DAFTAR PUSTAKA}

BSNP. 2006. Standar Isi Untuk Satuan Pendidikan Dasar dan Menengah. Jakarta: Badan Standar Nasional Pendidikan

Dwirahayu, G., Kustiawati, D., dan Yanti,RA. 2018. "Analisis

Kemampuan Berpikir Aljabar Siswa berdasarkan Miskonsepsi”. Makalah Dalam: Seminar Nasional Pendidikan Matematika dan Matematika Universitas
Muhamadiyah Tangerang, 24 Maret 2018 .

Griffin, C.C., dan Jitendra, A.K. 2009. "Word Problem-Solving Instruction in Inclusive Third-Grade Mathematics Classrooms". The Journal of Education Research. Vol. 102 (3), pp: 187-202.

Hayati, L. 2013. "Pembelajaran Pendidikan Matematika Realistik Untuk Mengembangkan Kemampuan Berpikir Aljabar Siswa". Makalah Dalam: Seminar Nasional Matematika dan Pendidikan Matematika Fakultas Matematika dan IPA Universitas Negeri Yogyakarta, 9 Nopember 2013.

Holmes, VL., Miedema, C., Niewkoop, L., dan Haugen, N. 2013. "Data-Driven Intervention: Correcting Mathematics Students' Misconception, not Mistakes". The Mathematics Educator. Vol. 23 (1), pp. $24-44$.

Jitendra, A.K., dan Jon R. Star. 2012. “An Exploratory Study Contrasting High and Low Achieving Students' Percent Word problem Solving". Learning and Individual Differences. Vol. 22 (1), pp. 151-158.

Kieran, C. 2004. "Algebraic Thinking In The Early Grades: What Is It?". The Mathematics Educator. Vol. 8 (1), pp. 139-151.

Kieran, C. 2011. "Conceptualizing the learning of algebraic technique: Role of task and technology". Makalah Dalam: ICME 11 Proceeding.

Knuth, E., dan Cai, J. 2011. Early Algebraization: A Global Dialogue from Multiple Perspective, Middle School Students' Understanding of Core Algebra Concept: Equivalence and Variable. New York: SpringerVerlag Berlin Heidelberg. 
NCTM. 2000. Principles and Standards for School Mathematics. Reston: The National Council of Teachers of Mathematics.Inc.

Patton, B., dan Santos, E. 2012. "Analyzing Algebraic Thinking Using "Guess My Number" Problems". International Journal of Instruction. Vol. 5 (1), pp: 5-22.

Radford, L. 2013. "The Progressive Development of Early Embodied Algebraic Thinking". Mathematics Eucation Research Group of Australasia.

Ruseffendi, H.E.T. 2006. Pengantar Membantu Guru Mengembangkan Kompetensinya dalam Pengajaran Matematika untuk Meningkatkan CBSA. Bandung: Tarsito.

Sanjaya, Wina. 2013. Perencanaan dan Desain Sistem Pembelajaran. Jakarta: Kencana Prenada Media Grup.

Vennebush; G.P., Marquez, E., dan Larsen, J. 2005. "Embedding Algebraic Thinking Throughout The Mathematics Curriculum". Mathematics Teaching In The Middle School . Vol. 11 (2), pp. 8693.

Warsitasari, W. 2015. "Berpikir Aljabar dalam Pemecahan Masalah Matematika". Jurnal APOTEMA. Vol. 1 (1).

Xin, Y.P., Jitendra, A.K, dan Buchman, A.D. 2005. "Effects of Mathematical Word ProblemSolving Instruction on Middle School Student with Learning Problems". The Journal of Special Education. Vol. 39 (3), pp. 181-192.

Xin, Y.P. 2008. "The Effec of SchemaBased Instruction in Solving Mathematics Word Problem: An Emphasis On Prealgebraic Conceptualization of Multiplicative
Relations". Journal for Research in Mathematics Education. Vol. 39.

Yunarni, A., Dassa, A., dan Asdar. 2015. "Profil Pemahaman Notasi Aljabar Ditinjau Dari Kemampuan Verbal Siswa Kelas V Sekolah Dasar". Jurnal Daya Matematika. Vol.3 (1). 
FIBONACCI : Jurnal Pendidikan Matematika dan Matematika

Volume 5 No. 2 Bulan Desember Tahun 2019 